Diabetologia 2, 240-246 (1971)

(C) by Springer-Verlag 1971

\title{
Hormonal and Metabolic Disturbances during Acute and Subacute Myocardial Infarction in Man*
}

\author{
G. BODEN
}

\author{
Department of Medicine, Rochester General Hospital and the University of Rochester School of Medicine, \\ Rochester, New York, USA \\ Received: February 1, 1971, accepted: April 23, 1971
}

Summary. To investigate the cause of glucose intolerance (GIT), frequently seen during acute myocardial infarction (AMT), seventeen males without history of diabetos were studied with intravenous glucose tolerance tests within seventy-two hours after uncomplicated myocardial infarction and again three weeks later. Seventy percent $(12 / 17)$ of the patients showed GIT during AMI. In 7 of these patients (41\%) glucose tolerance (GT) remained abnormal after 3 weelzs. In addition, all 7 showed markedly diminished insulin responses to glucose during both the acute and subacute phase. Therefore, their GIT was considered to be due to newly-recognized chemical diabetes. In the remaining patients in whom the initially depressed GT improved during SMT elevated serum levels of FFA, insulin, HGH and cortisol suggested the temporary presence of insulin antagonism. Increased adrenal medullary activity was not found to be a major factor inhibiting glucose tolerance.

Troubles hormonaux et métaboliques durant l'infarctus du myocarde aigu et subaigu chez l'homme

Résumé. Afin de rechercher la cause de l'intolérance au glucose qui se manifeste souvent à l'occasion d'un infarctus du myocarde aigu, nous avons étudié 17 sujets masculins non diabétiques au moyen de tests de tolérance au glucose intra-veineux dans les 72 heures qui ont suivi un infaretus du myocarde sans complications, et de nouveau 3 semaines plus tard. $70 \%(12 / 17)$ des sujets ont montré une intolérance au glucose pendant l'infarctus du myocarde aigu. Chez 7 de ces sujets $(41 \%)$, la tolérance au glucose est restée anormale après 3 semaines et, de plus, les 7 sujets ont montré des réponses d'insuline au glucose nettement diminuées durant la phase aigüe et subaigüe. Pour cette raison, nous avons considéré que leur intolérance au glucose était due à un diabète chimique. Chez les autres sujets qui ont montré une améliora- tion du test de glucose, au départ mal toléré, des taux élevés d'acides gras libres du sérum, de l'insuline, de l'hormone de croissance humaine et de la cortisone suggèrent la présence temporaire d'un antagonisme de l'insuline. L'augmentation des catécholamines ne semble pas être la raison principale de la mauvaise tolérance au glucose.

Hormonelle und metabolische Störungen während des akuten und subakuten Herzinfarktes

Zusammenfassung. Die möglichen Ursachen für dio während eines akuten Myokardinfarktes häufig beobachtete schlechte Glucosetoleranz wurden untersucht. An 17 männlichen Patienten wurden 72 Stunden nach einem unkomplizierten akuten Myokardinfarkt und drei Wochon später intravenöse Glukosetoleranzteste durchgeführt. $70 \%(12 / 17)$ aller Patienten zeigten während der akuten Phase eine anormale Glukosetoleranz. Bei 7 dieser Patienten blieb die Glukosetoleranz auch nach 3 Wochen noch abnormal. Diese 7 zeigten außerdem eine deutlich verminderte Insulinsekretion nach Glukosestimulierung während der akuten und der subakuten Phase. Daher wurden diese abnormalen Glukoseteste als Anzeichen eines neu erkannten Diabetes mellitus angesehen. Bei den übrigen Patienten, die nach einer anfänglich schlechten Glukosetoleranz während der subakuten Phase eine Besserung zeigten, ließ die Erhöhung der freien Fettsäuren, des Insulins, des Wachstumshormons und des Cortisonspiegels einen vorübergehenden Zustand von Insulinantagonismus vermuten. Eine erhöhte Katecholaminsekretion war kein Hauptfaktor bei der Entstehung der schlechten Glukosetoleranz des akuten Herzinfarktes.

Key-words: Glucoso intolerance, myocardial infarction, insulin response, insulin antagonism, FFA, HGH, cortisol levels, catecholamines.

\section{Introduction}

Acute myocardial infarction (AMI) is frequently associated with impaired glucose tolerance, the cause of which is poorly understood. This glucose intolerance is transient and in most cases only detectable with glucose tolerance tests [33, 7]. Stress-induced adrenal hyperactivity is generally considered to be responsible for this abnormality of glucose metabolism. In support of this hypothesis, increased urinary catecholamine

* Supported in part by the Genesee Valley Heart Association, Rochester, New York and PHS Research Grant No. 5 MOI RR349. excretion and elevated levels of serum cortisol have been reported in many patients after acute myocardial infarction $(32,14,10,16)$.

The present study was performed to further clarify the metabolic and humoral alterations present during the acute and subacute phase of myocardial infarction and to evaluate their relationship to glucose intolerance. To do this, intravenous glucose tolerance tests were performed in 17 patients with acute myocardial infaretion and again 3 weeks later. Measurements of serum glucose, insulin, growth hormone (HGH), free fatty acids (FFA), cortisol, cholesterol and triglycerides as well as 24 hour urinary excretion of vanillylmandelic acid (VMA) or catecholamines were performed. 


\section{Methods}

Patients: Seventeen male patients between 36 and 60 years of age (mean age 48.4 years) with acute myocardial infarction were studied between 48 and 72 hours after the onset of infarction and restudied three weeks later. Informed consent was received from all patients. The diagnosis of acute myocardial infarction was made in all patients on the basis of clinical history, elevation of serum transaminases and/or diagnostic electrocardiographic changes. Only patients who were stable at the time of testing and were free of significant ventricular arrhythmias (less than 5 ectopic beats per minute), pulmonary congestion or hypotension were studied. Patients were not selected for sex, however, only male patients with myocardial infarction were admitted to the hospital during the time of this study. All patients admitted to the study were nonobese (weight range $97-115 \%),{ }^{1}$ normokalaemic, without known liver di- comparable information on glucose utilization (Kvalue) [33], is innocuous, a good stimulatory test for insulin and a more physiologic test than IV insulin for growth hormone secretion. Previous studies in normal subjects have shown that intravenous glucose enhances insulin secretion (35) and frequently produces a rise of serum growth hormone 90 minutes or more after glucose infusion [23]. Tests were performed after an overnight fast with the patient at bedrest. Glucose $(0.5$ gram per kilogram body weight) was injected intravenously within three minutes as a $25 \%$ solution. Blood samples were drawn from an indwelling needle in an antecubital vein kept patent with a slow infusion of isotonic saline. Samples were obtained at 0, 10, 20, $30,40,50,60,90$ and 120 minutes after termination of the glucose injection.

Diet: The patients diet during the $48-72$ hours prior to the test consisted of a mixed soft diet supplemented with various amounts of dextrose in water

Table 1. $K$ values of glucose disappearance (percent-per minute) during intravenous glucose tolerance tests in patients with acute myocardial infarction (AMI) and three weeks later (SMI)

\begin{tabular}{|c|c|c|c|c|c|c|c|}
\hline & \multicolumn{4}{|c|}{ Group I } \\
\hline \multicolumn{2}{|c|}{$\begin{array}{l}\text { Group } \mathrm{II}^{\mathrm{a}} \\
\text { Pt. Age }\end{array}$} & $\mathrm{K}(\mathrm{AMI})$ & $\mathrm{K}(\mathrm{SMI})$ & Pt. \# & Age & $\mathrm{K}(\mathrm{AMI})$ & $\mathrm{K}(\mathrm{SMI})$ \\
\hline 1 & 39 & 0.95 & 1.17 & 2 & 54 & 0.73 & 1.09 \\
\hline 5 & 41 & 0.95 & 1.29 & 3 & 58 & 0.59 & 0.75 \\
\hline 6 & 40 & 1.45 & 2.26 & 4 & 42 & 0.70 & 1.09 \\
\hline 7 & 59 & 0.97 & 1.62 & 11 & 58 & 0.99 & 0.67 \\
\hline 8 & 43 & 1.19 & 1.48 & 12 & 45 & 0.97 & 1.12 \\
\hline 9 & 44 & 1.29 & $0.76^{\mathrm{b}}$ & 14 & 42 & 0.97 & 0.87 \\
\hline 10 & 63 & 1.59 & $0.95^{b}$ & 17 & 53 & 0.99 & 0.71 \\
\hline 13 & 52 & 0.83 & 2.12 & & & & \\
\hline 15 & 36 & 1.49 & 2.69 & & & & \\
\hline 16 & 56 & 0.57 & 1.49 & & & & \\
\hline$n$ & 10 & 10 & 10 & & 7 & 7 & 7 \\
\hline Mean & 47.30 & 1.13 & 1.58 & & 50.29 & 0.85 & 0.90 \\
\hline SEM & 2.98 & 0.10 & 0.18 & & 2.70 & 0.06 & 0.07 \\
\hline $\bar{P}$ & & & .05 & & & N & \\
\hline
\end{tabular}

a See text for criteria of classification for Group I and Group II

$\mathrm{b}$ 'These patients showed symptoms of a sympathetic reaction during the second test.

NS not significant $(P>0.05)$.

sease and none had diabetes or other endocrinopathies. None had received diuretics or cortical steroids. All but three patients had a history of coronary heart disease. Fifteen healthy male volunteers served as normal controls. The growth hormone and insulin data of this group have been reported in previous publications $[4,5]$. Insulin values were available in only 12 of these 1.5 controls. Because of a different technique to measure FFA used in this study, the FFA data of these normal controls could not be used. Instead, control FFA values have been taken from the literature [28].

Intravenous Glucose Tolerance Test (IVGTT): The IVGTT was selected because it provides precise and

1 From Metropolitan Life Insurance Tables, 1959. given intravenously resulting in a daily carbohydrate intake of between 200 and 300 grams.

Laboratory Measurements: Blood sugar was determined by the ferricyanide method of Hoffman, modified for use with the autoanalyzer [11]. Serum HGH and insulin were measured by double antibody radioimmunoassay techniques [26,3]. All HGH and insulin levels in this study were determined in a single assay in order to exclude possible fluctuations from assay to assay. Free fatty acids were measured by the micro colorimetric method of Duncomb [9], using the Dole extraction procedure [8]. VMA levels were measured by the method of Pisano [20] and catecholamines by the method of Sobel and Henry [25], both by BioScience Laboratories, Van Nuys, California. Normal limits for VMA are $0.7-6.8 \mathrm{mg} / 24 \mathrm{~h}$ and for catechol- 
amines up to $103 \mu \mathrm{g} / 24 \mathrm{~h}$. Total cholesterol was determined with the autoanalyzer with a modification of the Liberman-Burchard reagent [30]. Triglycerides were measured enzymatically with Biochemica Test Combination (Boehringer, Mannheim, Germany) [2]. Blood for serum cortisol determinations were drawn between $8 \mathrm{a} . \mathrm{m}$. and $10 \mathrm{a} . \mathrm{m}$. The samples were assayed by Dr. Don S. Schalch at the Strong Memorial Hospital, Rochester, New York, using Murphy's competitive protein-binding radioassay [18]. Normal values are from $6-26 \mu \mathrm{g} / 100 \mathrm{ml}$.

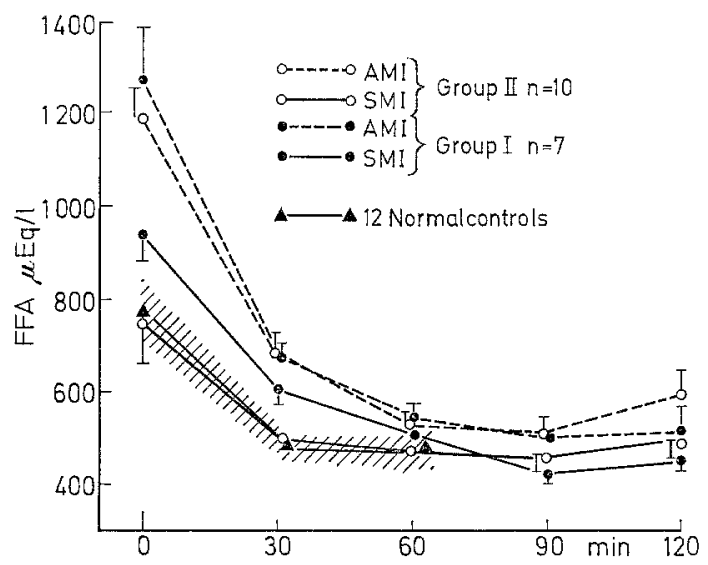

Fig. 1. Serum insulin concentration during intravenous glucose tolerance tests in patients with acute myocardial infarction (AMI) and three weeks later (SMT). The shaded area represents normal controls (mean \pm SEM). See text for criteria of classification into Group I and II as an approximation. Statistical analysis was performed using Student's t-test for paired and unpaired samples.

\section{Results}

Incidence of GIT: Fasting blood glucose was normal in all seventeen patients during the acute and subacute phase, the highest value being $104 \mathrm{mg} / 100 \mathrm{ml}$. In spite of this, twelve of the seventeen patients with AMI $(70 \%)$ showed diabetic glucose tolerance $(\mathrm{K}<1.00)$. On the basis of the glucose and insulin data obtained, the seventeen patients were divided into two groups. Group 1 includes seven patients with abnormal glucose tolerance and, in addition, marked blunting of the early insulin response to IV glucose during both AMI and SMI (Table 1, Figure 1). They were, therefore, considered to have chemical diabetes. Group II includes the remaining ten patients. In seven of these patients glucose tolerance was normal during one test and abnormal during the other. Two showed normal glucose tolerance during both tests. One patient (\#1) although demonstrating subnormal $\mathrm{K}$ values during AMI and SMI had good insulin responses on both occasions. The only patients in whom glucose tolerance had deteriorated between the first and the second test were patients \# 9 and \# 10. They had normal glucose tolerance during AMI and showed diabetic $\mathrm{K}$ values at the second test. Both exhibited marked apprehension and demonstrated transient tachycardia, diaphoresis and pallor at the beginning of the second test period. Their

Table 2. Early $(0-20 \mathrm{~min})$ and late (20-120 min) 'integrated serum insulin response' (2IRI) to intravenous glucose in patients with acute myocardial infarction ( $A M I$ ) and three weeks later (SMI) and in normal controls. (Mean $\pm S E M$ )

\begin{tabular}{|c|c|c|c|c|c|}
\hline$\Sigma I R I$ & AMI & & & SMI & \\
\hline$\mu \mathrm{U} \times \min / \mathrm{ml}$ & $0-20 \mathrm{~min}$ & & $20-120 \mathrm{~min}$ & $0-20 \mathrm{~min}$ & $20-120 \mathrm{~min}$ \\
\hline $\begin{array}{l}\text { Group II } \\
n=10\end{array}$ & $1779 \pm 264$ & $p<0.01$ & $\begin{array}{r}6455 \pm * 1305 \\
p<0.05\end{array}$ & $\begin{array}{r}1516 \pm 203 \\
p<0.01\end{array}$ & $\begin{array}{r}4.080 \pm 490 \\
p<0.001\end{array}$ \\
\hline $\begin{array}{l}\text { Group I } \\
u=1\end{array}$ & $727 \pm 97$ & & $3239 \pm 372$ & $744 \pm 116$ & $2610 \pm 314$ \\
\hline $\begin{array}{l}\text { Normal Controls } \\
n=12\end{array}$ & $\begin{array}{l}0-20 \mathrm{~min} \\
1548 \pm 159\end{array}$ & & $\begin{array}{l}20-120 \min \\
3927 \pm * * 538\end{array}$ & & \\
\hline
\end{tabular}

Significance of differences:

* Group II (20-120 min) AMT vs SMI

** Normal Controls $(0-20 \mathrm{~min})$ vs Group I $(0-20 \mathrm{~min})$

$p<0.05$

$p<0.01$

Calculations: The K-rate of glucose disappearance (percent glucose disappearing from the blood per minute) was calculated according to Wahlberg [33]. $K$-values above 1.20 were considered normal, $K$-values between 1.00 and 1.19 borderline abnormal, and Kvalues below 1.00 definitively diabetic [6]. Methods for direct measurement of total pancreatic insulin output in man are not available. Therefore, the area circumscribed by the serum insulin curve and expressed as microunits times minutes per milliliter, the so-called "integrated serum insulin response" ( $\Sigma$ IRI) was used impaired glucose tolerance during this test was, therefore, felt to be due to a sympathetic reaction. Unfortunately, both refused to be retested.

\section{Insulin}

Fasting serum insulin levels were normal (range $2-24 \mu \mathrm{U} / \mathrm{ml})$ in all patients.

Group I: As can be seen in Figure 1, there was, however, a marked blunting of the early insulin re- 
sponse during AMI and SMI in all seven patients. Consequently, the early "total integrated insulin response" of this group was significantly smaller than in both the normal controls and the Group II patients (Table 2).

Group II: Only patients \# 9 and \#10 showed clearly reduced insulin levels ( 36 and $40 \mu \mathrm{U} / \mathrm{ml}$ at the 10 minute interval during SMI), supporting our assumption that these patients experienced an epinephrine reaction during the second test. The other eight patients exhibited prompt and adequate insulin responses to IV glucose during AMI and SMI, resulting in mean insulin levels of 103 and $70 \mu \mathrm{U} / \mathrm{ml}$ respectively at the 10 minute interval. (Fig. 1). This early insulin rise was comparable with the one observed in healthy volunteers. However, while insulins in the normal controls reached maximal levels at 10 minutes and declined. thereafter, eight (all except \# 9 and \# 10) Group II patients demonstrated a continuous rise with peak insulin levels occuring between the 20 and 90 minute interval during AMI. This was reflected in considerably

\section{Growth Hormone}

Fasting HGH levels during both acute and subacute myocardial infarction were well within normal limits (less than $3 \mathrm{~m} \mu \mathrm{g} / \mathrm{ml}$ ) in all patients. During acute myocardial infarction, mean $\mathrm{HGH}$ concentration in Group II patients rose fourfold from a fasting level of $1.1 \mathrm{~m} \mu \mathrm{g} / \mathrm{ml}$ to a peak of $4.6 \mathrm{~m} \mu \mathrm{g} / \mathrm{ml}$ at the $60 \mathrm{~min}$ interval $(p<0.02)$ (Table 3). This rise was due to a significant increase in $\mathrm{HGH}$ concentration in seven of ten patients within one hour after glucose injection. The onset of this increase occurred at $30 \mathrm{~min}$ in four and at $60 \mathrm{~min}$ in three patients. By comparison, a growth hormone rise before the $60 \mathrm{~min}$ interval was seen in only two of the Group I patients and in none of fifteen healthy volunteers as shown in a previous publication [5]. During SMI such a paradoxical early HGH rise was observed in only one patient of either group. Peak HGH concentrations during acute myocardial infarction correlated well with peak insulin concentrations $(r=0.86, p<0.01)$.

Table 3. Serum growth hormone (mug/ml) during intravenous glucose tolerance tests in patients with acute myocardial infarction (AMI) and three weeks later (SMI) and in normal controls

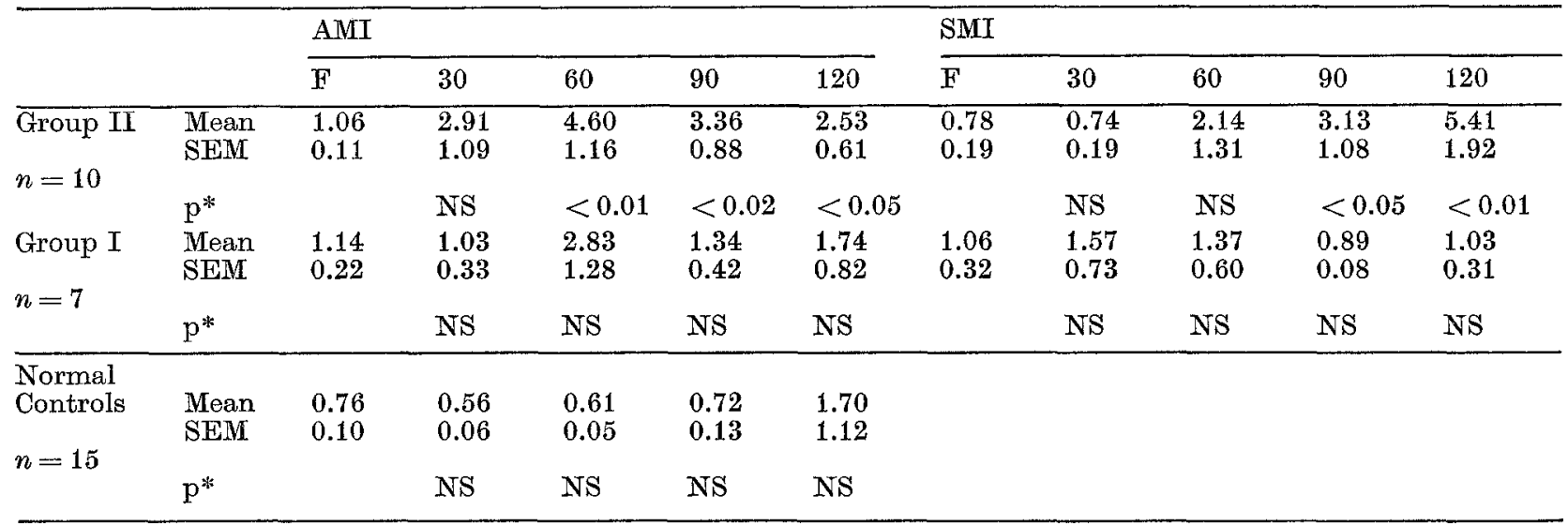

* Significance of difference from fasting HGH concentration

$\begin{array}{llll}\text { Normal controls vs Group II (AMI) } & 30 \text { min } & 60 \text { min } & 90 \text { min } \\ & p<0.05 & p<0.01 & p<0.01 \\ \text { Normal controls vs Group II (SMI) } & 90 \text { min } & & \\ & p<0.05 & \end{array}$

NS, not significant

greater than normal late "total integrated insulin" values. (Table 2). A clear trend towards improvement of insulin secretion in these patients was visible three weeks later. At this time, half of the patients showed maximum insulin levels at the ten minute interval and the mean late "total integrated insulin response" was the same as in the normal controls. The association of transient hyperinsulinism and a relatively depressed glucose tolerance suggested that some form of insulin antagonism was present in eight of the ten Group II patients.
Serum Cortisol and Urinary VMA or Catecholamines (Table 4): Serum cortisol levels were elevated in 6 of 9 Group II patients during AMI. Three weeks later cortisol concentrations had increased in four, decreased in five and were still abnormally high in five patients. There was no correlation between glucose tolerance and serum cortisol concentrations $(r-0.136, p<0.8)$. Cortisol was measured in four Group I patients and was found elevated in two of them during AMI and SMI. The $24 \mathrm{~h}$ urine excretion of VMA or catecholamines was within the normal limits in all but three patients (all in Group II) during AMI. 
Serum Triglycerides and Total Cholesterol (Table 5): Serum triglyceride and total cholesterol levels were within normal limits in most patients. In a few patients mild hyperlipidaemia was seen in one test but not in the other. No significant differences of mean triglyceride or total cholesterol levels comparing the acute and subacute phase of myocardial infarction were observed.

Free Fatty Acids (Fig. 2): Mean fasting free fatty acid levels were clearly elevated in all patients during AMI (range 925-1490). During SMI mean free fatty acid concentrations of the Group II patients had normalized, whereas those of the Group I patients remained elevated although to a lesser degree than during AMI. Free fatty acid levels (all 17 patients) showed a negative correlation with glucose disappearance (Kvalues) $(r=-0.70, p<0.01)$.

Table 4. Serum cortisol and 24 h urinary excretion of $V M A$ or catecholamines in patients with acute myocardial infarction ( $A M I$ ) and three weels later (SMI)

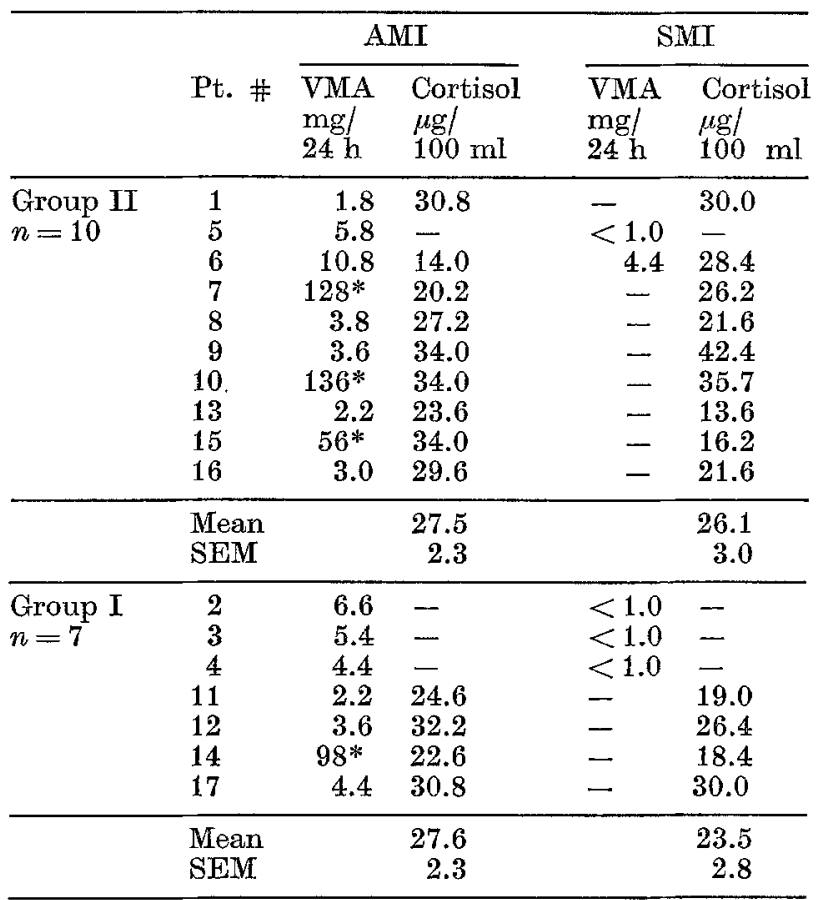

* Catecholamines $(\mathrm{mg} / 24 \mathrm{~h})$

\section{Discussion}

Seventy-percent of the patients in this study had diabetic glucose tolerance within $72 \mathrm{~h}$ after an acute myocardial infarction, although none of them had glucosuria or an abnormal fasting blood glucose. Three weeks later $24 \%$ still had diabetic and another $24 \%$ borderline abnormal glucose tolerance. These figures agree well with reports from other investigators. In Datey's series [7], abnormal glucose tolerance tests were seen in $65 \%$ of 145 patients within $72 \mathrm{~h}$ and in $29 \%$ one month after myocardial infarction. Sowton [29] studied 30 patients and found that glucose toler- ance was abnormal in $73 \%$ immediately after and in $43 \% 6$ months after infarction.

Known diabetogenic factors such as obesity, old age, hypokalaemia and treatment with diuretics or cortical steroids could be excluded in this study. Nevertheless, uncertainties remain. Almost all patients had received narcotics and/or analgetics, some lidocaine and others the anticoagulant sodium warfarin. There is at present little information on the influence of these drugs on glucose tolerance.

Table 5. Fasting serum cholesterol and triglyceride levels in patients with acute myocardial infarction ( $A M I)$ and three weeks later (SMI)

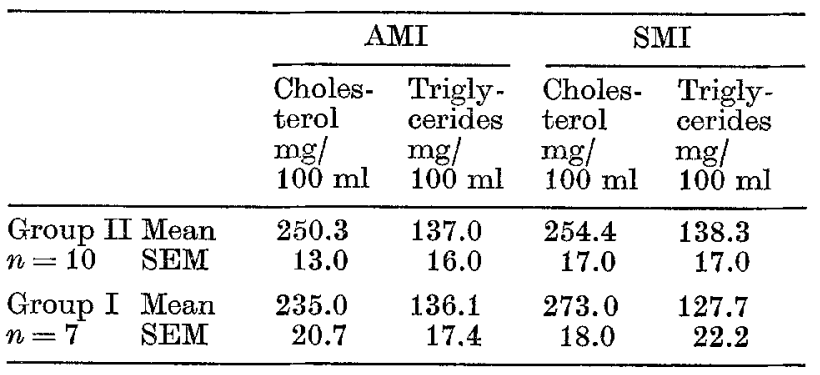

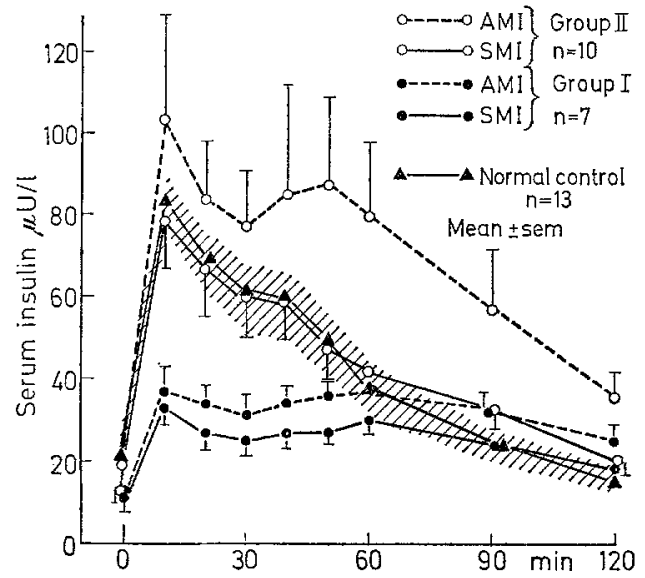

Fig. 2. Serum free fatty acid concentration (FFA) during intravenous glucose tolerance tests in patients with acute myocardial infarction (AMI) and three weeks later (SMI). The shaded area represents normal controls (mean \pm SEM). (Taken from Schalch et al. 9)

A high incidence of diabetic glucose tolerance has been found by many investigators in patients with ischaemic heart disease [23, 34]. Therefore, it was not surprising that seven of the 17 patients $(41 \%)$ who appeared to be diabetic could be separated from the rest. In these patients, diabetic or subnormal glucose tolerance, a blunted insulin response to glucose, and high fasting FFA levels were present during the acute phase and persisted through the subacute phase of the myocardial infarction. A diminished early insulin response to glucose has recently been shown to be characteristic of diabetes mellitus $[4,24,13]$. It would appear, therefore, that in these 7 patients glucose intolerance was primarily due to impaired insulin secretion i.e., 
diabetes. Certainly, longer follow-up studies in our seven patients will be necessary to determine whether their glucose tolerance remains permanently depressed and whether they will eventually become overtly diabetic, since it is well known that the results of intravenous glucose tolerance tests show some variation with time [33, 12]. Studying 74 patients post myocardial infarction, Wahlberg [33], however, found that whereas the individual variation of glucose tolerance was rather great at times, it did not often lead to a change in classification. Only $16 \%$ of his patients who initially had diabetic or borderline values were normal when re-examined from six to more than 24 months later.

Insulin secretion in Group II patients was found to be markedly different from the insulin hyposecretion seen in the "diabetic" Group I patients. The former responded promptly to intravenous glucose with adequate insulin output (patients \# 9 and \# 10 being the only exceptions). They showed, however, prolonged insulin secretion reaching peak insulin levels between 20 and $90 \mathrm{~min}$ after glucose infusion. This pattern of prolonged and consequently increased insulin secretion associated with glucose intolerance is frequently seen in conditions such as obesity, acromegaly, after injection of HGH, during late pregnancy and has also been reported in patients with ischaemic heart disease [31] and myocardial infarction $[19,15]$. It is considered to indicate insulin antagonism, i.e. a situation wherein insulin is partly prevented from manifesting its biological action, resulting in continuing $\beta$ cell stimulation and compensatory hypersecretion of insulin. Thus, it appears that insulin antagonism rather than deficiency might have had a major role in the aetiology of the depressed glucose tolerance in the majority of the Group II patients during acute myocardial infarction. The possibility that some of these patients (particularly Patient \# 1) might be diabeties as well cannot be excluded.

HGH is a well-known insulin antagonist. Evidence for a blood sugar regulatory role of physiological HGH fluctuations has been found by several laboratories $[17,27]$. Yalow et al. [36] performed repeated glucose tolerance tests in the same subjects, and found an almost constant association between the magnitude of the HGH response and the subsequent glucose intolerance several hours later. In this study, markedly abnormal growth hormone secretion was seen in the Group II patients showing signs of insulin antagonism. During AMI, 7 of these 10 patients compared with only $\mathbf{2}$ of $\mathbf{7}$ Group I patients had an increase in growth hormone during the first hour after glucose injection, at which time growth hormone secretion is completely suppressed in normals. The paradoxical early rise in serum HGH concentration during AMI and the normalization of the secretory pattern during SMI suggests that there was a transient disturbance of the hypothalamo-hypophyseal growth hormone releasing mechanism, the cause of which remains unknown. This disturbance was likely to result in an overall increased
$\mathrm{HGH}$ release since the pituitary glands of these patients probably responded to stimulatory and to normally suppressing impulses with secretion of HGH. The finding that the Group II patients with the highest HGH levels also showed the highest insulin levels would seem to support the thesis that HGH indeed exerted an anti-insulin effect during acute myocardial infarction. Results similar to ours showing that over $50 \%$ of patients with acute myocardial infarction have increased HGH secretion during the first $60 \mathrm{~min}$ of an intravenous glucose tolerance test were recently published by Lebovitz [15].

Fasting FFA levels in patients with acute myocardial infarction were almost twice as high as in normals. Their decrease during the subacute phase in Group II patients was paralleled by improved glucose tolerance. In addition, increasing FFA concentrations correlated well with decreasing $\mathrm{K}$-values in patients of this group.

Although these data do not conclusively establish, they are nevertheless suggestive of a cause and effect relationship between FFA and glucose intolerance. It is well known that a variety of hormones such as ACTH, TSH and glucagon produce elevated FFA concentration in several species under various experimental conditions $[22,1]$. HGH and the catecholamines presently are the only known substances for which it has been unequivocally demonstrated that endogenous secretion has adipo-kinetic effects. Urinary catecholamines were within normal limits in all but three patients. Growth hormone secretion, however, was abnormal and could conceivably have increased lipolysis resulting in decreased insulin sensitivity and a further increase of lipolysis. Cortisol levels were elevated in 6 of 9 Group II patients during AMI. Nevertheless, it appears questionable whether this insulin antagonist contributed significantly to their GIT since no correlation between serum cortisol and glucose tolerance was observed at any time.

Myocardial infaretion is commonly associated with considerable physical and psychological stress, resulting in increased adrenergic activity. It has been demonstrated that elevated levels of catecholamines are associated with inhibition of pancreatic insulin release in response to glucose [21] and increased FFA levels secondary to enhanced lipolysis. By either mechanism, catecholamines could conceivably impair glucose tolerance. In this study only three patients had elevated urinary VMA or catecholamines. These findings are consistent with the observations of others $[32,14,10]$, in which catecholamine excretion was not found to be significantly elevated in patients with uncomplicated myocardial infarction. These workers also found that catecholamine levels had returned to normal $48-72 \mathrm{~h}$ after infarction in those patients in which they were initially elevated. Therefore, it appears unlikely that catecholamines are an important factor responsible for the glucose intolerance found three days or more after uncomplicated myocardial infarction. 
Acknowledgements. I am indebted to Miss Gertrud von Hesberg and Miss Irene Dingeldein for technical assistance, to Miss Joan Eve and Mrs. Jackie Travitz for nursing services, to Dr. Milan Radivojevic for measuring serum cholesterol and triglycerides, to Drs. Don E. Kamm, Robert A. Heinle and Don S. Schalch for advice in preparing the manuscript and to Mrs. Kathy Clark and Mrs. Rachelle Masloff for secretarial help.

\section{References}

1. Astwood, E.B.: The pituitary gland and the mobilization of fat. Handbook of Physiology, sect. 5: Adipose tissue. Edited by Renold, A.E., Cahill, G.F. Washington, D.C.: Amer. Physiol. Soc., 1965, pp. 529-532.

2. Biochemica Test Combination No. 15989, Boehringer Mannheim, Germany

3. Boden, G., Soeldner, J.S.: A sensitive double antibody radioimmunoassay for human grow th hormone (HGH): levels of serum HGH following rapid tolbutamide infusion. Diabetologia 3, 413-421 (1967).

4. Boden, G., Soeldner, J.S., Gleason, R.E., Marble, A.: Elevated serum human growth hormone and decreased serum insulin in prediabetic males after intravenous tolbutamide and glucose. J. clin. Invest. 47, 729-739 (1968).

5. - - Steinke, J., Thorn, G.W.: Serum human growth hormone (HGH) response to IV glucose: Diagnosis of acromegaly in females and males. Metabolism 17, 1-9 (1968).

6. Conard, V.: Mesure de L'assimilation du glucose. Bases theoretiques et applications cliniques. Acta gastro-ent. belg. 18, 655-845 (1955).

7. Datey, K. K., Nanda, N.C. : Hyperglycemia after acute myocardial infarction. New Eng. J. Med. 276, 262265 (1967).

8. Dole, V.P.: A relation between non-esterified fatty acids in plasma and the metabolism of glucose. J. clin. Invest. 35, 150-154 (1956).

9. Duncombe, W.G.: The colorimetric micro determination of long chain fatty acids. Biochem. J. 88, 7-10 (1963).

10. Hayashi, K.D., Moss, A.J., Yu, P.N.: Urinary catecholamine excretion in myocardial infarction. Circulation 40, 473-481 (1969).

11. Hoffman, W.S.: A rapid photoelectric method for the determination of glucose in blood and urine. J. biol. Chem. 120, 51-55 (1937)

12. Kahn, C. B., Soeldner, J.S., Gleason, R.E., Rojas, L., Camerini-Davalos, R.A., Marble, A.: Clinical and chemical diabetes in offspring of diabetic couples. New Engl. J. Med. 281, 343-347 (1969).

13. Kipins, D.M.: Insulin secretion in diabetes mellitus. Ann. intern. Med. 69, $891-901$ (1968).

14. Klein, R.F., Troyer, W.G., Thompson, H.K., Bogdonoff, M.D., Wallace, A, G.: Catecholamine secretion in myocardial infarction. Arch. intern. Med. 86, $476-482$ (1968).

15. Lebovitz, H.E., Kirkwood, T.S., Matthews, M.E., Scheele, R.: Acute metabolic responses to myocardial infarction. Circulation 39, 171-181 (1969).

16. Logan, R.W., Murdoch, W.R.: Blood-levels of hydrocortisone, transaminases, and cholesterol after myocardial infarction. Lancet 1966 II, 521-524.

17. Luft, R., Cerasi, E., Madison, L.L., Von Euler, U.S., Della Casa, L., Roovete, A. : Effect of a small decrease in blood glucose on plasma growth hormone and urinary excretion of catecholamines in man. Lancet $\mathbf{1 9 6 6}$ II, $245-256$.

18. Murphy, B.E.P.: Some studies of the protein binding of steroids and their application of the routine micro and ultramioro measurement to various steroids in body fluids by competitive protein-binding radioassay. J. clin. Endocr. 27, 973-990 (1967).

19. Peters, N., Hales, C. N. : Plasma-insulin concentrations after myocardial infarction. Lancet $1965 \mathrm{I}, 1144-$ 1145.

20. Pisano, J.J., Crout, J.R., Abraham, D.: Determination of 3-methoxy-4-hydroxymandelic acid in urine. Clin. chim Acta 7, 285-291 (1962).

21. Porte, D., Graber, A.L., Kuzuya, T., Williams, R.H.: The effect of epinephrine on immunoreactive insulin levels in man. J. clin. Invest. 45, 228 $\rightarrow 236$ (1966)

22. Raben, M.S.: Regulation of fatty-acid release with particular reference to pituitary factors. Handbook of Physiology, Sect. 5: Alipose tissue. Edited by Renold, A.E., Cahill, G.F., Washington, D.C.: Amer. Physiol. Soc. 1965, pp. $331-334$.

23. Roth, J., Glick, S.M., Yalow, R. S., Berson, S.A.: The influence of blood glucose on the plasma concentration of growth hormone. Diabetes 13, 355-361 (1964).

24. Seltzer, H.S., Allen, E.W., Herron, A.L., Brennan, M.T.: Insulin secretion in response to glycemic stimulus. Relation of delayed initial release to carbohydrate intolerance in mild diabetes mellitus. J. clin. Invest. 46, 323-335 (1967).

25. Sobel, C., Henry, R.J.: Determination of catecholamines (adrenalin and noradrenalin) in urine and tissue. Am. J. cli. Path. 27, 240-245 (1957).

26. Soeldner, J.S., Slone, D.: Critical variables in the radioimmunoassay of serum insulin using the double antibody technique. Diabetes 14, 771-779 (1965).

27. - Sonksen, P.H., Gleason, R.E., Boden, G.: The possible role of growth hormone in the pathogenesis of diabetes mellitus. Actions of hormones. Edited by Foa, P. pp. 421-432. Springfield, Ill.: Charles C. Thomas Publisher 1971.

28. Schalch, D.S., Kipnis, D.M.: Abnormalities in carbohydrate tolerance associated with elevated plasma nonesterified fatty acids. J. clin. Invest. 44, 2010-2020 (1965).

29. Sowton, E.: Cardiac infarction and the glucose-tolerance test. Brit. med. J. 1962 I, 84-86.

30. Technicon auto analyzer catalog SMA $12 / 60$ p. 20. Technicon Corporation. Ardsley, N.Y.

31. Tzagournis, M., Seidensticker, J.F., Hamwi, G.J.: Serum insulin, carbohydrate, and lipid abnormalities in patients with premature coronary heart disease. Ann. intern. Med. 67, 42-47 (1967).

32. Valori, C, Thomas, M., Shillingford, J. : Free noradrenaline and adrenaline excretion in relation to clinical syndromes following myocardial infarction. Amer. J. Cardiol. 20, 605-617 (1967).

33. Wahlberg, F.: Intravenous glucose tolerance in myocardial infarction, angina pectoris and intermittent claudication. Acta med. seand. Suppl. 453, 180, 7-93 (1966).

34. - Thomasson, B.: Glucose tolerance in ischaemic cardiovascular disease. Carbohydrate metabolism and its disorders. Edited by Dickens, F., Randle, P.J., Whelan, W.J., pp. 185-196. London and New York: Academic Press 1968.

35. Yalow, R.S., Berson, S.A.: Immunoassay of endogenous plasma insulin in man. J. clin. Invest. 39, 1157$1175(1960)$.

36. - Goldsmith, S.J., Berson, S.A.: Influence of phy. siologic fluctuations in plasma growth hormone on glucose tolerance. Diabetes 18, 402-408 (1969).

Günther Boden, MD

Assistant Professor

Dept. of Medicine

Temple University Hospital

Philadelphia, Pa. 19140

USA 